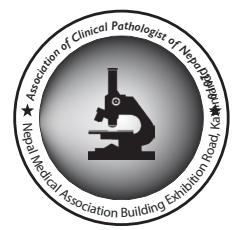

\title{
Aspiration and non-aspiration technique in the study of thyroid gland lesion cytology
}

\author{
Mainali Nirajan ${ }^{1}$, Nepal Niraj ${ }^{1}$, Choudhary Prabesh kumar ${ }^{1}$, Homagai \\ Neha $^{2}$, Khanal Bibek ${ }^{3}$ \\ ${ }^{I}$ Department of pathology, Nobel medical college teaching hospital, Biratnagar, Nepal. \\ ${ }^{2}$ Department of Obstetrics and Gynecology, Nobel medical college teaching hospital, Biratnagar, Nepal. \\ ${ }^{3}$ Department of Otolaryngology, head and neck surgery, Nobel medical college teaching hospital, Biratnagar, Nepal.
}

\section{Keywords: \\ Aspiration; \\ Non-aspiration; \\ Thyroid;}

\begin{abstract}
Background: Fine needle aspiration cytology is used as a primary diagnostic tool in thyroid lesions. But the bloody smears caused by negative pressure during aspiration compromise cellular concentration and cell morphology which may lead to its improper interpretation. FNNAC avoids active aspiration and depends on capillary tension to collect tissue sample in the needle bore, thus reducing bleeding and tissue trauma to the highly vascular thyroid.
\end{abstract}

Material and Methods: This is a one year prospective study where FNNAC and FNAC were done on 87 patients. Cytopathologist was blind folded regarding the technique used and was asked to score the quality of slide base of Mair scoring system.

Results: FNAC yielded significantly better material on the basis of hemorrhage and cellularity. Fifty six $(64.37 \%)$ cases showed adequate diagnostic material in FNNAC technique while 54/87 (62.05\%) cases showed adequate diagnostic material in FNAC technique. Twelve $(13.79 \%)$ cases showed unsuitable diagnostic material in FNNAC technique and 26/ 87 (29.89\%) cases unsuitable diagnostic material in FNAC technique. Among the individual criteria used in Mair scoring system, background clot/ blood was significantly low in FNNAC than FNAC with the p value less than 0.001 . Amount of cellular material was significantly more in FNNAC with p value less than 0.001 .

Conclusion: FNNAC yielded more cellular and less hemorrhagic material and more diagnostic superior material than FNAC. Since thyroid is a highly vascular gland, FNNAC should be used instead of FNAC for less hemorrhagic and more cellular material.

\section{Correspondence:}

Dr. Nirajan Mainali, MBBS, $M D$

Assistant Professor, Pathology

Nobel Medical College Teaching Hospital, BIratnagar, Nepal

Email:mainali_nirajan@hotmail.com

ORCID ID: 0000-0002-6648-1914

Reveived : September $2^{\text {nd }}, 2018$; Accepted : December 16 $6^{\text {th }}, 2018$; Published : March 21 ${ }^{\text {st }}, 2017$

Citation: Mainali N, Nepal N, Choudhary PK, Homagai N, Khanal B. Aspiration and non-aspiration technique in the study of thyroid gland lesion cytology. J Pathol Nep 2018: 8:1257-60. doi:10.3126/ jpn.v8i1.19446

Copyright: This is an open-access article distributed under the terms of the Creative Commons Attribution 4.0 International License, which permits unrestricted use, distribution, and reproduction in any medium, provided the original author and source are credited.

\section{INTRODUCTION}

Nodular thyroid lesions are one of the most common clinical problems, malignancy rate of which can be up to $10 \% .{ }^{1}$ Hence, early diagnosis and treatment has become important in these lesions. ${ }^{2}$ Fine needle aspiration cytology (FNAC) for lump was first done by Martin and Ellis in 1930 $\mathrm{AD}$ in the United States. ${ }^{3}$ Fine needle aspiration cytology is used as a primary diagnostic tool in thyroid lesions. ${ }^{4}$ It is minimal invasive technique with high sensitivity, specificity and accuracy. ${ }^{5}$ But the bloody smears caused by negative pressure during aspiration compromise cellular concentration and cell morphology which may lead to 
its improper interpretation. ${ }^{6}$ while working to find its solution Brifford et al in 1982 developed fine needle non aspiration cytology (FNNAC). ${ }^{7}$ But he used this technique in breast. This method is also called cytopuncture or fine needle capillary sampling or fine needle non aspiration. ${ }^{8}$ In thyroid this technique was first used by Santos and Leiman in $1988 .{ }^{9}$ FNNAC avoids active aspiration and depends on capillary tension to collect tissue sample in the needle bore, thus reducing bleeding and tissue trauma to the thyroid. ${ }^{2}$ In FNNAC, same bore needle as FNAC is used but it won't be attached to it. Needle is passed in a similar way as in FNAC in a lesion but the negative pressure is not created by the syringe. The content $\mathrm{s}$ of the needle is then spread on to the slide and interpretation is done after staining. ${ }^{4}$

Several studies have done in the past to find out diagnostic supremacy of FNNAC and/or FNAC. There were many conflicting results. This study is done to find out, if we can used FNNAC as a diagnostic tool instead of FNAC in thyroid.

\section{MATERIALS AND METHODS}

This is a prospective study carried out in Department of Pathology, Nobel medical college teaching hospital from September 1st, 2016 to August 31st, 2017. A total of 87 patients were included in the study. Both FNAC and FNNAC techniques were done in the same setting by the same pathologist irrespective of consistency and size. Permission from the institutional review committee was obtained. Patients with known case of thyrotoxicosis were not included in the study. After the procedure sample were labelled as A and B and was noted in the register. Cytopathologist was not aware about the technique used and the label in it to prevent the observation bias. For both procedures 22 gauze needle was used. FNAC was done with $10 \mathrm{ml}$ syringe attach to it. After the collection of the sample it was put in a clean and dry slide and smear was made. FNNACs sample was blew to the slide with the help of new $10 \mathrm{ml}$ syringe filled with air. After spreading sample, half of the sample from both techniques was immediately fixed with $95 \%$ ethyl alcohol. Half of the sample was allowed to air dried. Air dried sample were stain with May Grunwald Giemsa Stain and wet alcohol fixed slides were stained with Papanicolaou stain. Slides were then evaluated for background clot/blood, cellularity, degree of cellular degeneration, degree of cellular trauma and retention of appropriate architecture. For this Mair et al scoring system was adopted.10 (Table 1).

A cumulative score was given for each slide, ranging from 0 to 10 . It was then categorized into three categories as per score.

1. Category 1 (score $0-2$ ): smear not suitable for diagnosis.

2. Category 2 (score 3-6): smear suitable for cytological
Table 1: Point scoring system to classify quality of cytological aspirate $^{10}$

\begin{tabular}{|c|c|c|}
\hline Criteria & $\begin{array}{l}\text { Quantitative } \\
\text { description }\end{array}$ & Point score \\
\hline \multirow{3}{*}{$\begin{array}{l}\text { Background } \\
\text { blood/clot }\end{array}$} & $\begin{array}{l}\text { Large amount, great compromise of } \\
\text { diagnosis }\end{array}$ & 0 \\
\hline & Moderate amount, diagnosis possible & 1 \\
\hline & Minimal amount, diagnosis & 2 \\
\hline \multirow{3}{*}{$\begin{array}{l}\text { Amount of } \\
\text { cellular material }\end{array}$} & $\begin{array}{l}\text { Minimal to absent, diagnosis not } \\
\text { possible }\end{array}$ & 0 \\
\hline & Sufficient for cytodiagnosis & 1 \\
\hline & Abundant, diagnosis possible & 2 \\
\hline \multirow{3}{*}{$\begin{array}{l}\text { Degree of } \\
\text { cellular } \\
\text { degeneration }\end{array}$} & Marked, diagnosis impossible & 0 \\
\hline & Moderate, diagnosis possible & 1 \\
\hline & Minimal, diagnosis easy & 2 \\
\hline \multirow{3}{*}{$\begin{array}{l}\text { Degree of } \\
\text { cellular trauma }\end{array}$} & Marked, diagnosis impossible & 0 \\
\hline & Moderate, diagnosis possible & 1 \\
\hline & Minimal, diagnosis easy & 2 \\
\hline \multirow{3}{*}{$\begin{array}{l}\text { Retention of } \\
\text { appropriate } \\
\text { architecture }\end{array}$} & Minimal to absent, non-diagnostic & 0 \\
\hline & $\begin{array}{l}\text { Moderate, some preservation of, for } \\
\text { eg. Follicle, papillae, acini, flat sheets, } \\
\text { syncytia or single cell pattern }\end{array}$ & 1 \\
\hline & $\begin{array}{l}\text { Excellent architectural display closely } \\
\text { reflecting histology, diagnosis obvious }\end{array}$ & 2 \\
\hline
\end{tabular}

Table 2: Comparison of diagnostic quality between FNNAC and FNAC

\begin{tabular}{llc}
\hline \multirow{2}{*}{ Results } & \multicolumn{2}{c}{ TECHNIQUE } \\
\cline { 2 - 3 } & FNNAC & FNAC \\
& No. of cases (\%) & No. of cases (\%) \\
\hline Diagnostic superiority & $19(21.84)$ & $7(8.06)$ \\
\hline Diagnostic adequate & $56(64.37)$ & $54(62.05)$ \\
\hline Unsuitable & $12(13.79)$ & $26(29.89)$ \\
Total & $\mathbf{8 7 ( 1 0 0 )}$ & $\mathbf{8 7}(\mathbf{1 0 0})$ \\
\hline
\end{tabular}

Table 3: Frequency of various thyroid lesions

\begin{tabular}{|lll|}
\hline Type of lesion & No. of cases & $\%$ \\
\hline Colloid goiter & 25 & 28.73 \\
\hline Nodular goiter & 23 & 26.44 \\
\hline Thyroiditis & 16 & 18.39 \\
\hline Follicular lesion & 13 & 14.95 \\
\hline Follicular neoplasm & 2 & 2.30 \\
\hline Papillary carcinoma & 7 & 8.04 \\
\hline Medullary carcinoma & 1 & 1.15 \\
\hline Total & $\mathbf{8 7}$ & $\mathbf{1 0 0}$ \\
\hline
\end{tabular}

diagnosis

3. Category 3 (score 7-10): diagnostic superior smear.

The scores were the then tabulated and SPSS 17 software was used for data analysis. Chi square test was used. P value 
Table 4: Comparison of various studies

\begin{tabular}{|c|c|c|c|c|c|c|c|}
\hline & \multirow{2}{*}{ No. of cases } & \multicolumn{3}{|c|}{ FNNAC } & \multicolumn{3}{|c|}{ FNAC } \\
\hline & & DS & DA & $\mathrm{U}$ & DS & DA & $\mathrm{U}$ \\
\hline Rizvi et al ${ }^{20}$ & 150 & 67 & 80 & 3 & 30 & 110 & 10 \\
\hline Ramachandra et $\mathrm{al}^{4}$ & 69 & 14 & 47 & 8 & 5 & 47 & 17 \\
\hline Our study & 87 & 19 & 56 & 12 & 7 & 54 & 26 \\
\hline
\end{tabular}

of $<0.05$ was considered significant.

\section{RESULTS}

A total of 87 patients were included in our study. Seventy four of them were females and 13 were males. Table 1 shows the comparison of both techniques. Nineteen (21.84\%) cases showed diagnostic superiority in FNNAC technique while $7 / 87(8.06 \%)$ cases showed diagnostic superiority in FNAC. Two cases showed diagnostic superiority in both FNAC and FNNAC techniques.

Fifty six (64.37\%) cases showed adequate diagnostic material in FNNAC technique while 54/87 (62.05\%) cases showed adequate diagnostic material in FNAC technique. Thirty four cases showed adequate diagnostic material in both FNAC and FNNAC techniques.

Twelve (13.79\%) cases showed unsuitable diagnostic material in FNNAC technique and 26/87 (29.89\%) cases unsuitable diagnostic material in FNAC technique. Four cases showed unsuitable diagnostic material in both FNAC and FNNAC techniques.

Among the individual criteria used in Mair scoring system, background clot/ blood was significantly low in FNNAC than FNAC with the $p$ value less than 0.001. Amount of cellular material was significantly more in FNNAC with $\mathrm{p}$ value less than 0.001 . Degree of cellular degeneration, degree of cellular trauma and retention of appropriate architecture did not show any statistical significant between FNNAC and FNAC techniques.

Frequency of thyroid lesions encountered during the study was tabulated in table 3 . Goiter was the most common lesion $(\mathrm{n}=48 ; 55.17 \%)$ followed by thyroiditis $(\mathrm{n}=16 ; 18.39 \%)$.

\section{DISCUSSION}

FNAC since its inception has been accepted as a diagnostic tool in a nodular lesions by now. ${ }^{11}$ FNAC has been a primary diagnostic tool in case of thyroid nodule as it is easy to perform, rapid, less complication with high sensitivity and high specificity. ${ }^{12}$ Thyroid being a highly vascular glands, it is sometimes painful, traumatic and yield hemorrhagic material for cytological study. FNNAC which doesn't need negative pressure to collect the sample depends on a capillary action of the fine needle, where semi fluid or fluid substance ascends immediately in a tube, depending upon the diameter of the tube. ${ }^{9}$ Due to this reason the procedure is less painful and less traumatic. ${ }^{13}$

A total of 87 patients were included in our study. 22 gauze needles were used in our study. Torres et al14 and pinki et al also used needle of 22 gauze. 8 Others used needle of 25 gauze needle for the procedure. ${ }^{15-17}$

Background blood/ clot was significantly less in our study which was similar to the study done by Pinki et $\mathrm{al}^{8}$ and ramachandra et $\mathrm{al}^{4}$ but akther et al did not find significant difference ${ }^{18}$ but it was on the lymph node.

Cellularity was higher significantly higher in our study which was similar to the study done by Jayaram et a ${ }^{19}$ but Mair et $\mathrm{al}^{10}$ and zajdela et $\mathrm{al}^{3}$ did not find any significant difference between two techniques in terms of cellularity. Comparison of various studies is tabulated in table 4 .

\section{CONCLUSION}

FNNAC yielded more cellular and less hemorrhagic material and more diagnostic superior material than FNAC. Since thyroid is a highly vascular gland, FNNAC should be used instead of FNAC for less hemorrhagic and more cellular material.

\section{Conflict of interest: None}

\section{REFERENCES}

1. Gharib H. Fine-needle aspiration biopsy of thyroid nodules: advantages, limitations, and effect. Mayo Clin Proc. 1994;69:44-9. $\underline{\text { Crossref }}$

2. Song H, Wei C, Li D, et al. Comparison of Fine Needle Aspiration and Fine Needle Nonaspiration Cytology of Thyroid Nodules: A Meta-Analysis. Biomed Res Int. 2015;796120:29. Crossref

3. Zajdela A, Zillhardt P, Voillemot N. Cytological diagnosis by fine needle sampling without aspiration. Cancer. 1987;59:1201-5. $\underline{\text { Crossref }}$

4. Ramachandra L, Kudva R, Rao BH, Agrawal S. A Comparative Study of Fine Needle Aspiration Cytology (FNAC) and Fine Needle Non-aspiration Cytology (FNNAC) Technique in Lesions of Thyroid Gland. Indian J Surg. 2011;73:287-90. Crossref

5. Ramakrishnappa PKaS. "Cytological evaluation of thyroid lesions by fine needle aspiration versus nonaspiration cytology techniques - a comparative study,". International Journal of Current Research and Review, 2014;6:115-7.

6. Romitelli F, Di Stasio E, Santoro C, Iozzino M, Orsini A, Cesareo 
R. A comparative study of fine needle aspiration and fine needle non-aspiration biopsy on suspected thyroid nodules. Endocr Pathol. 2009;20:108-13. Crossref

7. Briffod M, Gentile A, Hebert H. Cytopuncture in the follow-up of breast carcinoma. Acta Cytol. 1982;26:195-200. Crossref

8. Pinki P, Alok D, Ranjan A, Nanak Chand M. Fine Needle Aspiration Cytology versus Fine Needle Capillary Sampling in Cytological Diagnosis of Thyroid Lesions. Iran J Pathol. 2015;10:47-53. Crossref

9. Santos JE, Leiman G. Nonaspiration fine needle cytology. Application of a new technique to nodular thyroid disease. Acta Cytol. 1988;32:353-6. Crossref

10. Mair S, Dunbar F, Becker PJ, Du Plessis W. Fine needle cytology--is aspiration suction necessary? A study of 100 masses in various sites. Acta Cytol. 1989;33:809-13. Crossref

11. Orell SR. Fine needle aspiration biopsy in perspective. Pathology. 1982;14:113-4. Crossref

12. Orell SR SG, Walters MNI, Whitaker D. Manual and Atlas of fine needle aspiration cytology. 3rd ed. Philadelphia: Churchill Livingstone; 1999.

13. Misra M CS, Bandyopadhyay SP. . Fine needle capillary sampling (Non aspiration technique) vs conventional FNAC in cytological diagnosis. Cytology. 2001;18:25-30.
14. M.R.Torres RJR, E. P. Leon Jr et al. "Punc ªo de tire'oide: valor da associac, ao de duas t'ecnicas,". Arquivos Brasileiros de Endocrinologia \&Metabologia. 2003;47:705-10. Crossref

15. Schoedel KE, Tublin ME, Pealer K, Ohori NP. Ultrasound-guided biopsy of the thyroid: a comparison of technique with respect to diagnostic accuracy. Diagn Cytopathol. 2008;36:787-9. Crossref

16. Z. Kashi ZT, O. Akha, A. Yaseri,M.H. Shahidi, and M. Mokhtare, . "Combination of aspiration and non-aspiration fine needle biopsy for cytological diagnosis of thyroid nodules,". Caspian Journal of Internal Medicine. 2011;2:299-303. Crossref

17. Ghosh A, Misra RK, Sharma SP, Singh HN, Chaturvedi AK. Aspiration vs nonaspiration technique of cytodiagnosis--a critical evaluation in 160 cases. Indian J Pathol Microbiol. 2000;43:107-12. Crossref

18. Akhtar SS HI, Faiz-U-Din M, Reyes LM. . Efficacy of fine needle capillary biopsy in the assessment of patients with superficial lymphadenopathy. Cancer Cytopathol 1997;81:277-80. Crossref

19. Jayaram G, Gupta B. Nonaspiration fine needle cytology in diffuse and nodular thyroid lesions: a study of 220 cases: Acta Cytol. 1991;35:789-90. Crossref

20. Rizvi SA, Husain M, Khan S, Mohsin M. A comparative study of fine needle aspiration cytology versus non-aspiration technique in thyroid lesions. Surgeon. 2005;3:273-6. Crossref 